\title{
THE CONCEPT OF A METHOD ENSURING AERONAUTICAL DATA QUALITY
}

\section{KONCEPCJA METODY ZAPEWNIENIA JAKOŚCI DANYCH LOTNICZYCH}

\author{
Ewa Dudek, Michał Kozlowski \\ Warsaw University of Technology, Faculty of Transport \\ emdudek@gmail.com,m.kozlowski@wt.pw.edu.pl
}

\begin{abstract}
The paper presents the concept of a method ensuring quality of aeronautical data. European Union (among others UE 73/2010) as well as international (among others ICAO Annex 15) regulations introduce a number of requirements regarding the quality and safety of aeronautical data. Those directives set up a complementary regulations system. However with their objective and scope they determine mainly the specifications and requirements that are to be implemented and compatible. Mentioned regulations also refer to selected international standards (e.g. ISO 19157), focused on quality and safety of geographic data and information. Nevertheless within the scope of considered regulations and norms no algorithms and methods of ensuring required quality in the process of aeronautical data collection and processing were determined. Taking into account the identified needs, authors proposed the application of statistical method for process quality management - six-sigma.
\end{abstract}

Keywords: aeronautical data, quality, safety, six-sigma

Streszczenie: Tematem publikacji jest koncepcja metody zapewnienia jakości danych lotniczych. Wspólnotowe (m.in. UE 73/2010) i międzynarodowe (m.in. Aneks 15 ICAO) przepisy prawne wprowadzaja szereg wymagań dotyczacych jakości $i$ bezpieczeństwa danych lotniczych. Przepisy te, tworza wzajemnie komplementarny system regulacji, ale swoim przedmiotem $i$ zakresem określaja głównie specyfikacje $i$ wymagania, które podlegaja obowiazkom wdrożenia $i$ zapewnienia zgodności. Przepisy te odwotuja się również do wybranych norm międzynarodowych (m.in. ISO 19157), których przedmiotem jest jakość $i$ bezpieczeństwo danych i informacji geograficznych. Jednak $w$ zakresie będacych przedmiotem rozważań przepisów $i$ norm nie określono algorytmów $i$ metod zapewnienia wymaganej jakości $w$ procesie gromadzenia $i$ przetwarzania danych lotniczych. W odniesieniu do stwierdzonych potrzeb, autorzy zaproponowali zastosowanie statystycznej metody zarządzania jakościa procesu - Six-Sigma.

Stowa kluczowe: dane lotnicze, jakość, bezpieczeństwo, six-sigma 
The concept of a method ensuring aeronautical data quality

Koncepcja metody zapewnienia jakości danych lotniczych

\section{THE CONCEPT OF A METHOD ENSURING AERONAUTICAL DATA QUALITY}

\section{Introduction}

Regulations (EC) No 549 $\div 552 / 2004$ of the European Parliament and the Council, the so-called „SES I Package" $[12,13,14]$ lay down the legal basis for creation of the Single European Sky - SES. According to the assumptions made actions taken under this initiative aimed at increasing safety and airspace capacity, while reducing the costs of providing air navigation services as well as the negative impacts of aviation on the environment.

Low effectiveness of the SES I decisions' implementation was the reason for release of the subsequent Regulation (EC) No 1070/2009 of the European Parliament and the Council [11], which deals with the change of regulations, falling within the scope of the first SES package, strengthening the aims and objectives of the SES policy, in particularly concerning the following issues:

- safety,

- environment protection,

- capacity,

- cost effectiveness.

One of the fundamental components of the Single European Sky is to provide integration and assure quality and safety of aeronautical data that is collected, processed, published and exchanged between different air navigation services' authorities, according to the established procedures and using specified systems.

The quality of aeronautical data delivered to air navigation services' representatives, clearly determine the safety and efficacy of EATMN network's interoperability, as well as management of the European airspace and its air traffic. The basic regulations in the field of aeronautical information were adopted and published in Annex 15 of ICAO. However, the EU Council recognized the SARPs of ICAO Annex 15 as the basis, but not providing effective and efficient achievement of the objectives set out in terms of SES. Due to this recognition, the succeeding documents, referring to the quality of aeronautical data, were issued, in particular Commission Regulation (EU) No 73/2010 laying down requirements on the quality of aeronautical data and aeronautical information for the single European sky and the specifications of the European Organisation for the Safety of Air Navigation including: EUROCONTROL Specification for Data Quality Requirements [15], EUROCONTROL Specification for the Origination of Aeronautical Data (DO) and EUROCONTROL Specification for Data Assurance Levels (DAL). Those documents also refer to the international ISO standards, regarding this problem, in particular to ISO standards series 19000. 
SES objectives will be achieved provided that inter alia the specifications are implemented, and the compliance of the aeronautical data with the regarding requirements is assured. Identified in this respect needs (arising from certain deficiencies concerning regulations and ISO standards), make it necessary to define in practice certain methods (and algorithms) ensuring aeronautical data quality.

\section{Overview of regulations, specifications and standards concerning aeronautical data quality}

Documents forming packages SES I [12, 13, 14] and II [11] form the legal basis for the concept of the Single European Sky. Regulation (EC) No 1070/2009 [11] draws attention to the fact that „The provision of modern complete, high-quality and timely aeronautical information has a significant impact on safety and on facilitating access to Community airspace and freedom of movement within it". At the same time, the Commission, in cooperation with Eurocontrol, undertook to ensure the availability of electronic aeronautical information of high quality, presented in a harmonized way and meeting the requirements of all users as to the quality and timeliness of data. Consequently, as stated in the regulation, "the modernisation and harmonisation of the provision of aeronautical information in its broadest sense in close cooperation with Eurocontrol and the ICAO" is necessary. As a result of the above mentioned commitments, in January 2010, Commission Regulation (EU) No 73/2010 laying down requirements on the quality of aeronautical data and aeronautical information for the single European sky [9], also known as Regulation ADQ was published. To be more accurate - the quality of data and aeronautical information in terms of accuracy, resolution and consistency. The discussed document defines the format of data exchange (Annex II), the requirements for formal arrangements (including the ranges of provided data and aeronautical information) for creation, processing and correction of data (Annex IV), as well as data protection (Annex VI). This last issue, in particular the need to protect all data transmitted in electronic form from loss or distortion through use of a CRC32Q (cyclic redundancy check) algorithm has already been discussed in another work of authors [1]. Going back to the quality of data and aeronautical information, the European Commission stated, inter alia, as follows:

1) Aeronautical data and aeronautical information of appropriate quality are required to ensure safety and support new concepts of operation within the European air traffic management network (EATMN).

2) The International Civil Aviation Organisation (ICAO) has defined aeronautical data and aeronautical information quality requirements in terms of accuracy, resolution and integrity that should be met and maintained within the EATMN when processing aeronautical data and aeronautical information.

3) Annex 15 to the Convention on International Civil Aviation [19] should provide the main baseline for the data quality requirements. 
The concept of a method ensuring aeronautical data quality

Koncepcja metody zapewnienia jakości danych lotniczych

4) Those ICAO requirements are considered to provide a sufficient baseline for current data quality requirements but there are known deficiencies that should be addressed, notably to support future applications.

5) Examination of the current situation has demonstrated that the quality requirements relating to aeronautical data and aeronautical information are not always met within the EATMN, in particular the accuracy and integrity requirements.

6) In accordance with the requirements of Regulation (EC) no 552/2004 [14], aeronautical information should be provided progressively in an electronic form, based on a commonly agreed and standardised data set. Those requirements should eventually be applicable to all aeronautical data and aeronautical information within the scope of this Regulation. Within the aeronautical data network, unfortunately, still a lot of things is done manually, on paper, which largely results in the possibility of the introduction of erroneous data and deterioration of their quality.

7) The timely provision and publication of new or amended aeronautical data and aeronautical information in accordance with the amendments and update cycle requirements of ICAO and Member States are considered essential to support the achievement of data quality.

While on the part of the statements or facts contained in paragraphs 1 to 7 (eg. 1, 2 or 7) it is impossible to disagree or argue, insomuch it is difficult to uncritically accept Annex 15 of ICAO [19] as the main (and perhaps the only one!) basis for the requirements for aeronautical data quality and at the same time a sufficient basis for the current quality requirements (points 3 and 4). The European Commission alone diagnoses the need of their modernization and clarification, partly in paragraphs 4 and 5 , and partly in thus far not presented passage of Regulation (EU) No 73/2010 [9] that states: "Eurocontrol has been mandated [..] to develop requirements supplementing and strengthening Annex 15 to the Chicago Convention in order to achieve aeronautical information of sufficient quality".

In order to meet this commitment in January 2013, the European Organisation for the Safety of Air Navigation has published the EUROCONTROL Specification for Data Quality Requirements [15]. This document lays down minimum requirements for accuracy, resolution and consistency of data and aeronautical information in the form of Harmonised List. This list draws on more than 20 pages and refers to such data as latitude, longitude, elevation/altitude/height, length/distance/dimension, etc., that is, de facto, most of all geospatial data as well as other data elements, to which Commission Regulation (EU) No 73/2010 [9] applies. Table 1 presents Harmonised List's headers with some sample data elements.

Again, the basis for determining (minimum) quality requirements of the data, presented in the Specification [9], is ICAO Annex 15 (Appendix 7) [19], especially in terms of resolution and data integrity. This is due to the fact that (as Eurocontrol writes): „The safety assessment performed during the development of the ADQ regulation, was predicated on the assumption that the current EATMN systems operating on the basis of the existing data quality requirements are tolerably safe". 
Aeronautical data accuracy requirements were supplemented with the requirements resulting from Annexes 11 [17] and 14 [18] ICAO. In addition to the Harmonized List some data elements not listed in Appendix 7 to ICAO Annex 15 [19] were added.

Table 1. Harmonised List - example of data (based on [15])

\begin{tabular}{|c|c|c|c|c|c|c|c|}
\hline REF ID & DATA ITEM & RESOLUTION & SOURCE & ACCURACY & SOURCE & $\begin{array}{l}\text { DATA } \\
\text { TYPE }\end{array}$ & $\begin{array}{c}\text { INTEGRITY } \\
\text { CLASSIFICATION }\end{array}$ \\
\hline LL032 & $\begin{array}{l}\text { De-icing/anti- } \\
\text { icing facility } \\
\text { (polygon) }\end{array}$ & $1 / 10 \mathrm{sec}$ & $\begin{array}{c}\text { Annex } \\
15\end{array}$ & $1 \mathrm{~m}$ & $\begin{array}{c}\text { Annex } \\
\text { 14, V1, } \\
\text { V2 }\end{array}$ & Surveyed & Routine \\
\hline EH001 & $\begin{array}{l}\text { Aerodrome } \\
\text { elevation }\end{array}$ & $1 \mathrm{~m}$ or $1 \mathrm{ft}$ & $\begin{array}{c}\text { Annex } \\
15\end{array}$ & $0,5 \mathrm{~m}$ & $\begin{array}{l}\text { Annex } \\
14, \text { V1 }\end{array}$ & Surveyed & Essential \\
\hline LD001 & $\begin{array}{c}\text { Airway segmen } \\
\text { length }\end{array}$ & $\begin{array}{c}1 / 10 \mathrm{~km} \text { or } 1 / 10 \\
\mathrm{NM}\end{array}$ & $\begin{array}{l}\text { Annex } \\
15\end{array}$ & $1 / 10 \mathrm{~km}$ & Annex 11 & Calculated & Routine \\
\hline
\end{tabular}

A set of aeronautical data quality requirements, published in Eurocontrol specification [15] as a Harmonised List takes into account the three data quality attributes, set out in Regulation ADQ (Annex IV, Part A, par. 5, subsections a) and b)) [9]. The other two attributes listed there, namely timeliness and traceability of data, are considered to be sufficiently dealt with in ICAO Annex 15 [19] and the regulation (EU) No 73/2010 [9], hence they are not under consideration in Eurocontrol Specification for Data Quality Requirements [15].

Since considering issues related to aeronautical data and information means dealing mainly with geospatial data, hence analyzing the problem of those data quality it is impossible to ignore the standard PN-EN ISO 19157:2014:04 - Geographic Information - Data Quality [7]. This standard, published in April 2014 replaces the previously issued standards numbered PN-EN ISO 19113:2009 - Geographic information - Fundamentals of quality description and PN-EN ISO 19114:2005 Geographic information - Procedures for assessing the quality. This standard, in contrast to the previously discussed document, does not define a minimum level of quality, sufficient for geographic data acceptance. Instead of this it (inter alia):

- defines the components for data quality description, including quality attributes of geographic data,

- describes the general procedures for evaluation of geographic data quality,

- determines the rules of data quality.

So far in all discussed documents more or less detailed requirements for aeronautical data and information quality were presented. Most often in a descriptive form, or as in the case of the Harmonised List in the form of definite values of accuracy, integrity and resolution specified for each data element separately. However, no document so far names methods to ensure the required quality or ways of its verification. 
The concept of a method ensuring aeronautical data quality

Koncepcja metody zapewnienia jakości danych lotniczych

In other words, no information on how to apply the data requirements and, above all, how to prove their fulfilment can be found. The ISO 19157 standard [7] as the first one discusses the procedure of data quality evaluation, but only in a descriptive manner, where the process of data quality evaluation is understood as a sequence of steps leading to the final evaluation of data quality.

To sum up, the requirements for aeronautical data include: resolution, integrity, accuracy (as defined by ICAO standards), completeness [7], timeliness and the ability to determine the origin of the data (as defined in Regulation ADQ [9]). This set of requirements determines the quality attributes of aeronautical data.

Assuming for further considerations the concept of quality, defined as the degree in which a set of inherent characteristics meet the requirements [6], the quality of aeronautical data - $J$ can be expressed as a finite set of attributes describing the qualitative properties [2], understood as the inherent property associated with the requirement [6]:

where:

$$
J=\left\{c_{1}, c_{2}, c_{3}, c_{4}, c_{5}, c_{6}\right\}
$$

$J$ - quality;

$c_{1}$ - quality characteristic for resolution,

$c_{2}$ - quality characteristic for integrity,

$c_{3}$ - quality characteristic for timeliness,

$c_{4}$ - quality characteristic for accuracy,

$c_{5}$ - quality characteristic for completeness,

$c_{6}$ - quality characteristic for origin of the data.

For the quality of aeronautical data stated in (1), it is possible to define a set of quality states $-J_{S}$ :

where:

$$
J_{S}=\left\{s_{1}, s_{2}, s_{3,} s_{4}, s_{5}, s_{6}\right\}
$$

$J_{S}$ - quality state,

$s_{i}$ - state (value) of $i$ qualitative state.

Based on the set of operational information quality states presented in (2) the quality level $-J_{P}$, dependent on the level of quality characteristics, was defined:

where:

$$
J_{P}=\left\{p_{1}, p_{2}, p_{3}, p_{4}, p_{5}, p_{6}\right\}
$$

$J_{P}$ - quality level,

$p_{i}-$ level of $i$ quality characteristic:

$$
p_{i}=s_{i R}-s_{i W}
$$

$s_{i R}-$ real state of the $i$ quality characteristic,

$s_{i W}-$ required state of the $i$ quality characteristic. 
From the speculations presented above results identified by the authors need to develop and implement a systematic method (inspection, evaluation, validation) of aeronautical data assurance, implemented at all stages of aeronautical data chain, starting with data creation and development, through the stages of storage, processing and transfer, ending with the stage of publication of aeronautical data and information. Mentioned method should assure expression of specified aeronautical data quality attributes in a measurable way and point out the basic structure for aeronautical data quality management.

\section{Statistical quality management according to Six-Sigma method}

Standard of such method has been defined in a series of international ISO standards ISO 13053 [3, 4], which in particular specify:

- multi-criteria statistical method of process quality management - Six-Sigma,

- assumptions and basic structure for process quality management.

Six-Sigma method belongs to the so-called "new quality management tools" [5]. It was developed in the twentieth's century $80 \mathrm{~s}$. and implemented to production process management in Motorola company. Six-Sigma method is based on a process approach and the principle of continuous statistical improvement DMAIC (Define $\rightarrow$ Measure $\rightarrow$ Analyse $\rightarrow$ Improve $\rightarrow$ Control) [3]

Table 2. Stages of DMAIC principle

\begin{tabular}{|c|l|}
\hline $\begin{array}{c}\text { DMAIC } \\
\text { Stage }\end{array}$ & \multicolumn{1}{|c|}{ Scope and objectives of work } \\
\hline Define & $\begin{array}{l}\text { Determination of requirements and critical quality } \\
\text { characteristics. }\end{array}$ \\
\hline Measure & $\begin{array}{l}\text { Determination of measurable goals as well as parameters and } \\
\text { results of the process. } \\
\text { Establishment of measurement and data collection procedures. }\end{array}$ \\
\hline Analyse & $\begin{array}{l}\text { Statistical analyzes of the collected data. } \\
\text { Evaluation of results, using specified criteria. }\end{array}$ \\
\hline Improve & $\begin{array}{l}\text { Planning and putting into effect appropriate action's types: } \\
\text { improvement, prevention or correction to ensure and maintain } \\
\text { compliance of the process results with the requirements. }\end{array}$ \\
\hline Control & $\begin{array}{l}\text { Continuous monitoring of the parameters and process results' } \\
\text { compatibility. }\end{array}$ \\
\hline
\end{tabular}

The objective of the Six-Sigma method is to minimize the number of incompatibility occurrence and their consequences which are costs of process losses by ensuring stability and process capability.

Six-Sigma method [4] is based on the assumptions that process results take the form of the normal distribution (used to describe phenomena of stochastic independent variables, eg. incompatibilities related to the method, machine, infrastructure), described with the average value $-\mu$ and standard deviation $-\sigma$ as well as achievement of conformity within $\pm \sigma$ from the average value $-\mu$, which ensures the likelihood of non-compliance at the level of 3.4 DPMO (Defects Per Million Opportunities) [2, 16]: 
The concept of a method ensuring aeronautical data quality

Koncepcja metody zapewnienia jakości danych lotniczych

$$
f(x)=\frac{1}{\sqrt{2 \pi \sigma}} \exp \left[-\frac{(x-\mu)^{2}}{2 \sigma^{2}}\right]
$$

where:

$\mu$ - average value;

$\sigma-$ standard deviation.

Six-Sigma method principles refer to the generally observed phenomenon, consisting in the fact that the process stability and ability to meet specific quality requirements, gradually (practically unnoticeable) decreases, but only the incompatibilities of process results were detected, which prevented current process corrections.

Six-Sigma strategy is based on preventive actions undertaken during the process functioning, and commercially available computer applications (eg.: Statistica, Minitab, JMP) and methodological standards of statistical quality management [16] serve to complement the same statistical method.

The basic statistical parameter characterizing quality process' capability in the SixSigma method is process capability index $-C_{P}$ :

$$
C_{P}=\frac{T}{6 \sigma}
$$

where:

$T$ - tolerance width,

$\sigma-$ standard deviation.

The value of $-C_{P}$ index determines the quality capability of the process:

$C_{P} \in(0,1) \quad-$ process incapable,

$C_{P} \in\langle 1,1.33\rangle \quad-$ average quality capability of the process,

$C_{P} \in(1.33,1.66)-$ good quality capability of the process,

$C_{P} \in(1.66, \infty) \quad-$ very good quality capability of the process.

The value of $-C_{P}$ index determines the need to take appropriate action regarding the process, such as:

- monitoring, analysis and corrective action,

- monitoring, analysis and preventive action,

- monitoring, analysis and continuous improvement,

- monitoring and analysis.

In case of the aeronautical data, that is under consideration, it should be noted that the Six-Sigma method assumes symmetrical distribution of the tolerance width to the process average value $-\mu$, while the rules [9] and specifications [15] related to the subject under discussion define the requirements for the nominal value. 
That is why in this case, it is necessary to apply process' nominal quality capability index $-C_{P N}$ :

where:

$$
C_{P N}=\frac{T}{6 \sqrt{\sigma^{2}+(\mu-N)^{2}}}
$$

$$
\begin{aligned}
& T \text { - tolerance width, } \\
& \sigma-\text { standard deviation, } \\
& \mu \text {-average value, } \\
& N \text { - nominal value. }
\end{aligned}
$$

For the distinguished attributes and quality characteristics (1) the nominal quality capability of the process can be expressed as:

where:

$$
C_{P N d l}=\left\{C_{P N 1}, C_{P N 2} C_{P N 3}, C_{P N 4}, C_{P N 5}, C_{P N 6}\right\}
$$

$C_{P N d l}$ - a set of indexes of the nominal process' capacity concerning aeronautical data processing,

$C_{P N 1}$ - process' nominal quality capability index for resolution,

$C_{P N 2}$ - process' nominal quality capability index for integrity,

$C_{P N 3}$ - process' nominal quality capability index for timeliness,

$C_{P N 4}$ - process' nominal quality capability index for accuracy,

$C_{P N 5}$ - process' nominal quality capability index for completeness,

$C_{P N 6}$ - process' nominal quality capability index for origin of the data.

In the practical implementation of the proposed method, the tolerance width - $T$ and the nominal value - $N$, will be assumed in accordance with legal requirements [9] and specifications [15]. Standard deviation $-\sigma$ and the average value $-\mu$ will be calculated up to date. Jointly they will determine the value of the $C_{P N}$ index, and thereby determine the necessary actions to be taken.

In the practical application of the proposed method of aeronautical data statistical quality assurance an important issue will be the establishment of specific algorithms and procedures for Six-Sigma method implementation, including assigning to particular units and entities their range of tasks, authorities and responsibility.

Assuming ISO 13053 standard [3, 4] (including the principle of DMAIC) to the practical application the requirements, measures, criteria and algorithms to analyze compliance of aeronautical data quality, improvement activities procedures (preventive, corrective) as well as the structures and rules for compliance monitoring within the entire data chain (considered as the process) of aeronautical data collection and processing will be clearly defined. They should include all process participants (units and air navigation services) and take into account the legally defined scope of their competence.

Those issues will be the subject of authors' further studies. 
The concept of a method ensuring aeronautical data quality

Koncepcja metody zapewnienia jakości danych lotniczych

\section{Conclusions}

Legislative processes of the EU related to civil aviation introduce new requirements which main goal is to ensure traffic and air transport safety. The regulation packages SES I and II, Regulation (EU) No 73/2010 and other related documents determine requirements and specifications for the quality of aeronautical data, which in particular areas refer to selected ISO standards. Those requirements go far beyond the ICAO standards, both in relation to the requirements level as well as in relation to responsibility scopes of the entities involved in aeronautical data collection and processing. Practical difficulties in meeting these requirements, which may also have the effect of lowering the level of air traffic safety, result of some shortcomings in the introduced regulations. Introduced regulations apply only to individual compliance checks of aeronautical data. This makes it necessary to develop a method of ongoing evaluation and continuous quality assurance of aeronautical data and information in accordance with the legal requirements introduced. Considering the issue of aeronautical data collection and processing as a process and taking into account that the analyzed regulations require the use of specific ISO standards, the authors proposed the use of statistical method of quality management process in accordance with ISO 13053 $[3,4]$ taking into account the fact that the current issue of particular ISO standards form a set of harmonized standards, mutually complementary in their scope and application.

\section{Literature}

[1] Dudek E., Kozłowski M.: Zagadnienie bezpieczeństwa zintegrowanych informacji operacyjnych w porcie lotniczym, Logistyka 4/2015, pages 183-192.

[2] Hamrol A., Mantura W.: Zarządzanie jakością - teoria i praktyka. PWN, Warsaw - Poznań 1998.

[3] ISO 13053-1:2011, Quantitative methods in process improvement - Six Sigma - Part 1: DMAIC methodology.

[4] ISO 13053-2:2011, Quantitative methods in process improvement - Six Sigma - Part 2: Tools and techniques.

[5] Kozłowski M., Stelmach A.: Implementacja narzędzi zarządzania jakością w systemie zarządzania bezpieczeństwem na lotnisku, Instytut Badań Systemowych Polska Akademia Nauk, Seria Badania Systemowe, Volume 63, Warsaw 2008, pages 257-266.

[6] PN-EN ISO 9000:2015-10, Quality management systems - Fundamentals and vocabulary, 2015.

[7] PN-EN ISO 19157:2014:04, Geographic Information - Data quality, 2014.

[8] PN-ISO/IEC 27001:2007, Technika informatyczna - Techniki bezpieczeństwa - Systemy zarządzania bezpieczeństwem informacji, 2007. 
[9] Commission Regulation (EU) No 73/2010 laying down requirements on the quality of aeronautical data and aeronautical information for the single European sky.

[10] Regulation (EC) No 216/2008 of the European Parliament and the Council of 20 February 2008 on common rules in the field of civil aviation and establishing a European Aviation Safety Agency and repealing Council Directive 91/670/EEC, regulation (EC) 1592/2002 and directive 2004/36/EC.

[11] Regulation (EC) No 1070/2009 of European Parliament and the Council of 21 October 2009 amending Regulations (EC) No 549/2004, (EC) No 550/2004, (EC) No 551/2004 and (EC) No 552/2004 in order to improve the performance and sustainability of the European aviation system.

[12] Regulation (EC) No 549/2004 of European Parliament and the Council of 10 March 2004 laying down the framework for the creation of the single European sky.

[13] Regulation (EC) No 550/2004 of European Parliament and the Council of 10 March 2004 on the provision of air navigation services in the single European sky.

[14] Regulation (EC) No 550/2004 of European Parliament and the Council of 10 March 2004 on the interoperability of the European Air Traffic Management.

[15] EUROCONTROL Specification for Data Quality Requirements, ref. number: EUROCONTROL-SPEC-152.

[16] Wodecka - Hyjek A.: Zastosowanie metody Six Sigma do doskonalenia wybranego procesu produkcyjnego w przedsiębiorstwie, Zeszyty Naukowe Akademii Ekonomicznej w Krakowie, Nr 736/2007, pages 61-73.

[17] Annex 11 to the Convention on International Civil Aviation, Air Traffic Services, International Civil Aviation Organization, July 2001.

[18] Annex 14 to the Convention on International Civil Aviation, Aerodrome Standards, International Civil Aviation Organization, July 2009.

[19] Annex 15 to the Convention on International Civil Aviation, Aeronautical Information Services, International Civil Aviation Organization, July 2013.

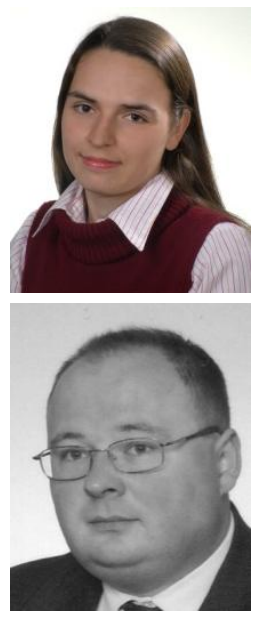

mgr in. Ewa Dudek works as an assistant in the Telecommunication Department at Warsaw University of Technology, Faculty of Transport. Scientific interests cover transport telematics, system integration, issues related to air traffic control as well as automation of continuous processes.

(Share: $50 \%$ ).

Michat Koztowski-Assistant Professor in the Department of Air Transport Engineering at Warsaw University of Technology, Faculty of Transport. Extensive experience in airport managing, gained from over twenty years of work in the operating area of Warsaw Chopin Airport. Author of numerous studies, publications and implementations in the field of safety, quality, reliability and capacity. (Share: 50\%). 
The concept of a method ensuring aeronautical data quality

Koncepcja metody zapewnienia jakości danych lotniczych

\section{KONCEPCJA METODY ZAPEWNIENIA UJAKOŚCI DANYCH LOTNICZYCH}

\section{Wstęp}

Rozporządzenia Parlamentu Europejskiego i Rady (WE) 549 552/2004, tzw. „Pakiet SES I” [12, 13, 14] tworzą podstawy prawne koncepcji Jednolitej Europejskiej Przestrzeni Powietrznej (ang. Single European Sky - SES). Według przyjętych założeń działania podjęte $\mathrm{w}$ ramach tej inicjatywy miały na celu podniesienie poziomu bezpieczeństwa i zwiększenie przepustowości przestrzeni powietrznej, przy jednoczesnym zmniejszeniu kosztów zapewniania służb żeglugi powietrznej i ograniczeniu negatywnego wpływu ruchu lotniczego na środowisko. Stwierdzona mała skuteczność realizacji postanowień Pakietu SES I była przyczynkiem do wydania przez Parlament Europejski i Radę kolejnego Rozporządzenia (WE) nr 1070/2009 [11], którego przedmiotem są zmiany rozporządzeń wchodzących w zakres Pakietu SES I, wzmacniające założenia i cele polityki SES, w szczególności dotyczące zagadnień:

- bezpieczeństwa,

- ochrony środowiska,

- przepustowości,

- efektywności kosztowej.

Jednym z podstawowych komponentów Jednolitej Europejskiej Przestrzeni Powietrznej jest zapewnienie integracji oraz jakości i bezpieczeństwa danych lotniczych, które są gromadzone i przetwarzane oraz publikowane i wymieniane pomiędzy organami poszczególnych służb żeglugi powietrznej, według ustanowionych procedur i przy wykorzystaniu określonych systemów. Jakość danych lotniczych, dostarczanych służbom żeglugi powietrznej, w oczywisty sposób determinuje bezpieczeństwo i skuteczność interoperacyjności sieci $($ EATMN) i zarządzania europejską przestrzenią powietrzną i ruchem lotniczym. Podstawowe regulacje $w$ zakresie informacji lotniczych zostały przyjęte i opublikowane w Aneksie 15 ICAO. Rada UE uznała jednak SARPs Aneksu 15 ICAO jako podstawę, ale niezapewniającą skutecznego i efektywnego osiągania celów określonych $\mathrm{w}$ zakresie SES. Z uwagi na to wydane zostały kolejne dokumenty, odnoszące się do zagadnienia jakości danych lotniczych, w tym w szczególności Rozporządzenie Komisji (UE) nr 73/2010 ustanawiające wymagania dotyczące jakości danych i informacji lotniczych dla jednolitej europejskiej przestrzeni powietrznej oraz specyfikacje Europejskiej Organizacji ds. Bezpieczeństwa Żeglugi Powietrznej w tym: Specyfikacja Eurocontrol Wymagania jakości danych lotniczych [15], Specyfikacja Eurocontrol - Tworzenie danych lotniczych oraz Specyfikacja Eurocontrol - Poziomy ufności danych lotniczych. Dokumenty te odwołują się również do międzynarodowych standardów ISO z zakresu tego zagadnienia w tym w szczególności do norm ISO serii 19000. 
Cele SES zostaną osiągnięte pod warunkiem, że m.in. zostaną wdrożone specyfikacje i będzie zapewniona zgodność danych lotniczych z wymaganiami. Stwierdzone w tym zakresie potrzeby (wynikające $\mathrm{z}$ pewnych braków $\mathrm{w}$ przedmiocie regulacji prawnych i norm ISO), czynią koniecznym określenie w praktyce pewnych metod (i algorytmów) zapewnienia jakości danych lotniczych.

\section{Studium przepisów, specyfikacji i norm dotyczących jakości danych lotniczych}

Dokumenty pakietów SES I [12, 13, 14] i II [11] tworzą podstawy prawne koncepcji Jednolitej Europejskiej Przestrzeni Powietrznej. Rozporządzenie (WE) nr 1070/2009 [11] zwraca uwagę na fakt, iż „Dostarczenie nowoczesnej, pełnej, wiarygodnej i aktualnej informacji lotniczej ma znaczący wpływ na bezpieczeństwo oraz ułatwianie dostępu i swobodę poruszania się wewnątrz przestrzeni powietrznej Wspólnoty”. Jednocześnie Komisja, we współpracy z Eurocontrolem, zobowiązała się zapewnić dostępność elektronicznej informacji lotniczej o wysokiej jakości, prezentowanej w sposób ujednolicony i spełniającej wymagania wszystkich użytkowników co do jakości i aktualności danych. Co za tym idzie, jak stwierdza omawiane rozporządzenie, konieczna jest „modernizacja i ujednolicenie udostępniania najszerzej rozumianej informacji lotniczej” w ścisłej współpracy z Eurocontrolem oraz Organizacją Międzynarodowego Lotnictwa Cywilnego - ICAO. W efekcie ww. zobowiązań w styczniu 2010 roku opublikowano rozporządzenie Komisji (UE) nr 73/2010 ustanawiające wymagania dotyczące jakości danych i informacji lotniczych dla jednolitej europejskiej przestrzeni powietrznej [9], zwane również rozporządzeniem ADQ. Dla uściślenia - jakości danych i informacji lotniczych pod względem dokładności, rozdzielczości i spójności. Omawiany dokument określa format wymiany danych (załącznik II), wymagania dotyczące ustaleń formalnych (w tym zakresy dostarczanych danych i informacji lotniczych) tworzenia, przetwarzania oraz korygowania danych (załącznik IV), jak również ochrony danych (załącznik VI). Ostatnie zagadnienie, w tym w szczególności konieczność ochrony wszelkich danych przekazywanych $\mathrm{w}$ formie elektronicznej przed utratą lub zniekształceniem dzięki stosowaniu algorytmu CRC32Q (cyklicznej kontroli nadmiarowej), zostało już omówione w innej pracy autorów [1]. Jeśli zaś mowa o samej jakości danych i informacji lotniczych Komisja Europejska stwierdza między innymi, co następuje:

1) Odpowiednia jakość danych i informacji lotniczych to wymóg służący zapewnieniu bezpieczeństwa i wspieraniu nowych koncepcji działania w ramach europejskiej sieci zarządzania ruchem lotniczym (EATMN).

2) Organizacja Międzynarodowego Lotnictwa Cywilnego (ICAO) określiła wymagania, dotyczące jakości danych i informacji lotniczych pod względem dokładności, rozdzielczości i spójności, które należy spełnić oraz utrzymywać w ramach EATMN przy przetwarzaniu tych danychi informacji.

3) Za główną podstawę wymagań dotyczących jakości danych należy przyjąć SARPs Aneksu 15 ICAO [19]. 
The concept of a method ensuring aeronautical data quality

Koncepcja metody zapewnienia jakości danych lotniczych

4) Wspomniane wymagania ICAO uważa się za dostateczną podstawę dla aktualnych wymagań dotyczących jakości, ale stwierdzono pewne braki, którymi należy się zająć, przede wszystkim w celu wsparcia przyszłych zastosowań.

5) Analiza aktualnej sytuacji wykazała, że w EATMN nie zawsze są spełniane wymagania dotyczące jakości danych i informacji lotniczych, zwłaszcza te odnoszące się do dokładności i spójności.

6) Zgodnie z wymogami Rozporządzenia (WE) nr 552/2004 [14] informacje lotnicze należy stopniowo zapewniać $\mathrm{w}$ formie elektronicznej na podstawie wspólnie uzgodnionego i ujednoliconego zbioru danych. Wymogi te należy ostatecznie stosować do wszystkich danych i informacji lotniczych. W sieci danych lotniczych niestety nadal wykonuje się dużo czynności ręcznie, na papierze, co $\mathrm{w}$ znacznym stopniu skutkuje możliwością wprowadzenie błędnych danych oraz pogorszenia ich jakości.

7) Za zasadniczy warunek osiągnięcia odpowiedniej jakości danych uważa się terminowe zapewnianie oraz publikowanie nowych lub zmienionych danych i informacji lotniczych zgodnie ze zmianami oraz $\mathrm{z}$ wymaganiami ICAO i państw członkowskich dotyczącymi cyklu aktualizacji danych.

O ile z częścią stwierdzeń lub faktów zawartych w podpunktach od 1 do 7 (np. 1, 2 czy 7) nie sposób się nie zgodzić czy polemizować, o tyle trudno bezkrytycznie uznać Aneks 15 ICAO [19] jako główną (a może nawet jedyną!) podstawę wymagań dotyczących jakości danych lotniczych oraz dostateczną podstawę dla aktualnych wymagań dotyczących jakości (punkty 3 i 4). Sama Komisja Europejska diagnozuje potrzebę ich modernizacji i uściślenia, częściowo $\mathrm{w}$ punktach $4 \mathrm{i} 5$, a częściowo $\mathrm{w}$ nieprzytoczonym dotąd fragmencie rozporządzenia (UE) $\mathrm{nr}$ 73/2010 [9], mówiącym, iż „W celu zapewnienia dostatecznej jakości informacji lotniczych organizacji Eurocontrol zlecono opracowanie wymagań uzupełniających i ugruntowujących Załącznik 15 do konwencji chicagowskiej".

W celu spełnienia tego zobowiązania w styczniu 2013 roku Europejska Organizacja ds. Bezpieczeństwa Żeglugi Powietrznej opublikowała Specyfikację Eurocontrol - Wymagania jakości danych lotniczych [15]. Dokument ten ustanawia minimalne wymagania w zakresie dokładności, rozdzielczości i spójności danych i informacji lotniczych w postaci Zharmonizowanej Listy. Lista ta ciągnie się na ponad 20 stron i dotyczy takich danych jak: szerokość i długość geograficzna, wzniesienie/wysokość bezwzględna/wysokość względna, długość/odległość/wymiar, itp., czyli de facto głównie danych geoprzestrzennych oraz innych elementów danych, do których ma zastosowanie Rozporządzenie Komisji (UE) nr 73/2010 [9]. Nagłówki tabel Zharmonizowanej Listy z kilkoma przykładowymi elementami danych przedstawia tabela 1 .

Ponownie podstawą określenia (minimalnych) wymagań jakościowych danych, przedstawionych w Specyfikacji [9], jest Aneks 15 ICAO (Dodatek 7) [19], zwłaszcza w zakresie rozdzielczości i spójności danych. 
Wynika to z faktu, iż (jak pisze Eurocontrol): „Analiza bezpieczeństwa, która została przeprowadzona podczas etapu opracowania rozporządzenia ADQ zakładała, że systemy EATMN wykorzystujące dane zgodne $\mathrm{z}$ istniejącymi wymaganiami jakości, są bezpieczne”. Wymagania z zakresu dokładności danych lotniczych uzupełniono o wymagania, wynikające z Aneksów 11 [17] i 14 [18] ICAO. Ponadto do Zharmonizowanej Listy dodano kilka elementów danych, niewymienionych w Dodatku 7 do Załącznika 15 ICAO [19].

Tabela 1. Zharmonizowana Lista-przyktad danych (opracowanie na podstawie [15])

\begin{tabular}{|c|c|c|c|c|c|c|c|}
\hline Lp. & $\begin{array}{c}\text { DANE } \\
\text { LOTNICZE }\end{array}$ & $\begin{array}{c}\text { ROZDZIELCZOŚĆ } \\
\text { PUBLIKACJI }\end{array}$ & ŹRÓDLO & DOKLADNOŚć & ŹRÓDLO & $\begin{array}{c}\text { TYP } \\
\text { DANYCH }\end{array}$ & $\begin{array}{c}\text { KLASYFIKACJA } \\
\text { SPÓJNOŚCI } \\
\text { (zgodnie z } \\
\text { Załącznikiem 15 } \\
\text { do Konwencji) }\end{array}$ \\
\hline LL032 & $\begin{array}{c}\text { Płaszczyzna } \\
\text { odladzania } \\
\text { (wielokąt) } \\
\text { (lotnisko) }\end{array}$ & $1 / 10$ sekundy & $\begin{array}{c}\text { Załącznik } \\
15 \text { do } \\
\text { Konwencji }\end{array}$ & $1 \mathrm{~m}$ & $\begin{array}{c}\text { Załącznik } \\
14 \text { do } \\
\text { Konwencji, } \\
\text { Tom I }\end{array}$ & Zmierzone & Zwykła \\
\hline EH001 & $\begin{array}{c}\text { Wzniesienie } \\
\text { lotniska }\end{array}$ & 1 metr lub 1 stopa & $\begin{array}{c}\text { Załącznik } \\
15 \text { do } \\
\text { Konwencji }\end{array}$ & $0,5 \mathrm{~m}$ & $\begin{array}{c}\text { Załącznik } \\
14 \text { do } \\
\text { Konwencji, } \\
\text { Tom I }\end{array}$ & Zmierzone & Ważna \\
\hline LD001 & $\begin{array}{c}\text { Długość } \\
\text { segmentu } \\
\text { drogi } \\
\text { lotniczej }\end{array}$ & $1 / 10 \mathrm{~km}$ lub $1 / 10$ & $\begin{array}{c}\text { Załącznik } \\
15 \text { do } \\
\text { Nonwencji }\end{array}$ & $1 / 10 \mathrm{~km}$ & $\begin{array}{c}\text { Załącznik } \\
11 \text { do } \\
\text { Konwencji }\end{array}$ & Obliczone & Zwykła \\
\hline
\end{tabular}

Zbiór wymagań w zakresie jakości danych lotniczych, opublikowany w specyfikacji Eurocontrol [15] jako Zharmonizowana Lista, uwzględnia trzy atrybuty jakości danych, wymienione w rozporządzeniu ADQ (załącznik IV, część A, pkt. 5, podpunkty a) i b)) [9]. Pozostałe dwa wymienione tam atrybuty, czyli terminowość oraz możliwość ustalenia pochodzenia danych, uznaje się za wystarczająco omówione w Aneksie 15 ICAO [19] oraz samym Rozporządzeniu (UE) nr 73/2010 [9], stąd nie są one przedmiotem rozważań w specyfikacji Eurocontrol - Wymagania jakości danych lotniczych [15].

Ponieważ rozpatrując zagadnienia, związane $\mathrm{z}$ danymi i informacjami lotniczymi ma się głównie do czynienia $\mathrm{z}$ danymi geoprzestrzennymi, stąd analizując problem jakości tych danych nie sposób pominąc normy PN-EN ISO 19157:2014:04 Informacja Geograficzna - Jakość danych [7]. Norma ta, opublikowana w kwietniu 2014 roku, zastępuje wcześniej wydane normy o numerach PN-EN ISO 19113:2009 - Informacja geograficzna - Podstawy opisu jakości oraz PN-EN ISO 19114:2005 - Informacja geograficzna - Procedury oceny jakości. Norma ta, w przeciwieństwie do omówionych wcześniej dokumentów, nie definiuje minimalnego poziomu jakości, pozwalającego na akceptację danych geograficznych. W zamian za to (między innymi):

- określa składowe opisu jakości danych, w tym również atrybuty jakości danych geograficznych,

- opisuje ogólne procedury oceny jakości danych geograficznych,

- określa zasady raportowania jakości danych.

We wszystkich omówionych, jak dotąd dokumentach, przedstawione były mniej lub bardziej szczegółowo wymagania dotyczące jakości danych i informacji lotniczych. Najczęściej w postaci opisu lub też jak w przypadku Zharmonizowanej Listy w postaci konkretnych wartości rozdzielczości, spójności i dokładności, określonych dla każdego elementu danych osobno. W żadnym jak dotąd 
The concept of a method ensuring aeronautical data quality

Koncepcja metody zapewnienia jakości danych lotniczych

dokumencie, nie wspomina się jednak o metodach zapewnienia wymaganej jakości ani o sposobach jej weryfikacji. Innymi słowy o informacjach w jaki sposób stosować wymagania dotyczące danych, a przede wszystkim, jak udowodnić ich spełnianie. Norma ISO 19157 [7] jako pierwsza omawia samą procedurę oceny jakości danych, jednakże jedynie w sposób opisowy, gdzie proces ewaluacji jakości danych jest rozumiany jako sekwencja kroków, prowadząca do końcowej oceny jakości danych.

Reasumując, wymagania odnośnie danych lotniczych dotyczą: rozdzielczości, spójności, dokładności (co definiują standardy ICAO), kompletności [7], terminowości oraz pochodzenia danych lotniczych (co określa rozporządzenie ADQ [9]). Zbiór tych wymagań wyznacza atrybuty jakościowe danych lotniczych.

Przyjmując do dalszych rozważań pojęcie jakości, definiowanej jako stopień, w jakim zbiór inherentnych właściwości spełnia wymagania [6], jakość danych lotniczych $-J$ można wyrazić jako pewien skończony zbiór cech opisujących właściwości jakościowe [2], rozumiane jako inherentna właściwość związana z wymaganiem [6]:

gdzie:

$$
J=\left\{c_{1}, c_{2}, c_{3}, c_{4}, c_{5}, c_{6}\right\}
$$

$J$ - jakość;

$c_{1}$ - cecha jakościowa dotycząca rozdzielczości,

$c_{2}$ - cecha jakościowa dotycząca spójności,

$c_{3}$ - cecha jakościowa dotycząca terminowości,

$c_{4}$ - cecha jakościowa dotycząca dokładności,

$c_{5}$ - cecha jakościowa dotycząca kompletności,

$c_{6}-$ cecha jakościowa dotycząca pochodzenia danych lotniczych.

Dla tak zdefiniowanej jakości danych lotniczych (1) zdefiniowano zbiór stanów jakości $-J_{S}$ :

gdzie:

$$
J_{S}=\left\{s_{1}, s_{2}, s_{3,} s_{4}, s_{5}, s_{6}\right\}
$$

$J_{S}-$ stan jakości,

$s_{i}-\operatorname{stan}$ (wartość) $i$-tej cechy jakościowej.

$\mathrm{Na}$ tak zapisanym zbiorze stanów jakości informacji operacyjnych (2) zdefiniowano poziom jakości $-J_{P}$, który zależny jest od poziomu cech jakościowych:

gdzie:

$$
J_{P}=\left\{p_{1}, p_{2}, p_{3}, p_{4}, p_{5}, p_{6}\right\}
$$

$J_{P}-$ poziom jakości,

$p_{i}-$ poziom $i$-tej cechy jakościowej,

$$
p_{i}=s_{i R}-s_{i W}
$$

$s_{i R}-$ rzeczywisty stan $i$-tej cechy jakościowej,

$s_{i W}-$ wymagany stan $i$-tej cechy jakościowej. 
Z powyższych rozważań wynika zidentyfikowana przez autorów konieczność opracowania i wdrożenia systemowej metody zapewnienia jakości (kontroli, ewaluacji, walidacji) danych lotniczych, na wszystkich etapach łańcucha danych lotniczych, poczynając od tworzenia i opracowywania, poprzez etapy przechowywania, obróbki, przetwarzania, przekazywania, kończąc na rozpowszechnianiu danych i informacji lotniczych. Metoda ta powinna zapewniać wyrażanie określonych atrybutów jakościowych danych lotniczych w sposób mierzalny oraz wyznaczać ramową strukturę zarządzania jakością danych lotniczych.

\section{Statystyczne zarządzanie jakością procesu wg metody Six-Sigma}

Standard takiej metody został określony w serii międzynarodowych norm ISO 13053 [3, 4], które w szczególności specyfikują:

- wielokryterialną statystyczną metodę zarządzania jakością procesu - SixSigma,

- założenia i strukturę ramową zarządzania jakością procesu.

Metoda Six-Sigma należy do tzw. „nowych narzędzi zarządzania jakością” [5]. Została opracowana w latach 80 . XX w. i wdrożona do zarządzania procesami produkcyjnymi koncernu Motorola. Metoda Six-Sigma opiera się na podejściu procesowym i zasadzie ciągłego doskonalenia statystycznego DMAIC (ang.: Define $\rightarrow$ Measure $\rightarrow$ Analyse $\rightarrow$ Improve $\rightarrow$ Control) [3]

Tabela 2. Etapy zasady DMAIC

\begin{tabular}{|l|l|}
\hline \multicolumn{1}{|c|}{$\begin{array}{c}\text { Etap } \\
\text { DMAIC }\end{array}$} & \multicolumn{1}{c|}{ Zakres i cele dzialania } \\
\hline Define & Określenie wymagań i krytycznych cech jakościowych. \\
\hline Measure & $\begin{array}{l}\text { Ustalenie mierzalnych celów i parametrów przebiegu i wyników } \\
\text { realizacji procesu. } \\
\text { Ustanowienie procedury pomiarów i gromadzenia danych. }\end{array}$ \\
\hline Analyse & $\begin{array}{l}\text { Analizy statystyczne zgromadzonych danych. } \\
\text { Ocena i ewaluacja wyników, z zastosowaniem określonych } \\
\text { kryteriów. }\end{array}$ \\
\hline Improve & $\begin{array}{l}\text { Zaplanowanie i podjęcie odpowiednich działań: doskonalących, } \\
\text { zapobiegawczych lub korygujących, w celu zapewnienia } \\
\text { i utrzymania zgodności wyników realizacji procesu } \\
\text { z wymaganiami. }\end{array}$ \\
\hline Control & $\begin{array}{l}\text { Ciągle monitorowanie parametrów i zgodności wyników } \\
\text { realizacji procesu. }\end{array}$ \\
\hline
\end{tabular}

Celem metody Six-Sigma jest minimalizacja liczby wystąpień niezgodności i będących tego następstwem kosztów strat $\mathrm{w}$ procesie, poprzez zapewnienie stabilności i zdolności procesu. 
The concept of a method ensuring aeronautical data quality

Koncepcja metody zapewnienia jakości danych lotniczych

Metoda Six-Sigma [4] opiera się na przyjęciu założenia o postaci rozkładu normalnego (wykorzystywanego do opisu zjawisk niezależnych stochastycznie zmiennych, np. niezgodności związanych z metodą, maszyną, infrastrukturą) wyników realizacji procesu, opisywanych wartością średnią $-\mu$ i odchyleniem standardowym $-\sigma$ oraz celu osiągania zgodności w granicach $\pm \sigma$ od wartości średniej - $\mu$, co zapewnia prawdopodobieństwo wystąpienia niezgodności na poziomie 3,4 DPMO (ang.: Defects Per Million Opportunities) [2, 16]:

$$
f(x)=\frac{1}{\sqrt{2 \pi \sigma}} \exp \left[-\frac{(x-\mu)^{2}}{2 \sigma^{2}}\right]
$$

gdzie:

$\mu$ - wartość średnia;

$\sigma$ - odchylenie standardowe.

Założenia metody Six-Sigma odnoszą się do powszechnie zaobserwowanego zjawiska, polegającego na tym, że stabilność i zdolność procesu do spełnienia określonych wymagań jakościowych, stopniowo (praktycznie niezauważalnie) obniża się, ale wykrywane były dopiero niezgodności wyników realizacji procesu, co uniemożliwiało bieżące korygowanie procesu.

Strategia Six-Sigma opiera się na działaniach prewencyjnych, podejmowanych $\mathrm{w}$ trakcie realizacji procesu, a uzupełnieniem samej metody statystycznej są dostępne na rynku aplikacje komputerowe (np.: Statistica, Minitab, JMP) i metodyczne standardy statystycznego zarządzania jakością w procesach [16]. Podstawowym parametrem statystycznym, charakteryzującym zdolność jakościową procesu w metodzie Six-Sigma, jest wskaźnik zdolności procesu $-C_{P}$ :

gdzie:

$$
C_{P}=\frac{T}{6 \sigma}
$$

$T$ - szerokość pola tolerancji,

$\sigma$ - odchylenie standardowe.

Wartość wskaźnika $-C_{P}$ określa zdolność jakościową procesu:

$$
\begin{aligned}
& C_{P} \in(0,1) \quad-\text { proces niezdolny jakościowo, } \\
& C_{P} \in\langle 1,1.33\rangle \quad-\text { przeciętna zdolność jakościowa procesu, } \\
& C_{P} \in(1.33,1.66\rangle \text { - dobra zdolność jakościowa procesu, } \\
& C_{P} \in(1.66, \infty) \quad-\text { bardzo dobra zdolność jakościowa procesu. }
\end{aligned}
$$

Wartość wskaźnika zdolności procesu $-C_{P}$ wyznacza konieczność podjęcia odpowiednich działań odnośnie procesu, takich jak:

- monitorowanie, analiza i działania korygujące,

- monitorowanie, analiza i działania zapobiegawcze,

- monitorowanie, analiza i ciągłe doskonalenie,

- monitorowanie i analiza. 
W przypadku będących przedmiotem rozważań danych lotniczych należy zwrócić uwagę, że metoda Six-Sigma zakłada symetryczne rozłożenie szerokości pola tolerancji względem wartości średniej - $\mu$ wyniku realizacji procesu, a dotyczące przedmiotu rozważań przepisy [9] i specyfikacje [15] określają wymagania odnośnie wartości nominalnej. W takim przypadku koniecznym jest zastosowanie wskaźnika nominalnej zdolności jakościowej procesu $-C_{P N}$ :

$$
C_{P N}=\frac{T}{6 \sqrt{\sigma^{2}+(\mu-N)^{2}}}
$$

gdzie:

$T$ - szerokość pola tolerancji,

$\sigma$ - odchylenie standardowe,

$\mu-$ wartość średnia,

$N$ - wartość nominalna.

Dla wyróżnionych atrybutów i cech jakościowych (1) nominalną zdolność jakościową procesu można wyrazić:

gdzie:

$$
C_{P N d l}=\left\{C_{P N 1}, C_{P N 2} C_{P N 3}, C_{P N 4}, C_{P N 5}, C_{P N 6}\right\}
$$

$C_{P N d l}$ - zbiór wskaźników nominalnej zdolności procesu przetwarzania danych lotniczych,

$C_{P N 1}$ - wskaźnik nominalnej zdolności jakościowej procesu dotyczący rozdzielczości,

$C_{P N 2}$ - wskaźnik nominalnej zdolności jakościowej procesu dotyczący spójności,

$C_{P N 3}$ - wskaźnik nominalnej zdolności jakościowej procesu dotyczący terminowości,

$C_{P N 4}$ - wskaźnik nominalnej zdolności jakościowej procesu dotyczący dokładności,

$C_{P N 5}$ - wskaźnik nominalnej zdolności jakościowej procesu dotyczący kompletności,

$C_{P N 6}$ - wskaźnik nominalnej zdolności jakościowej procesu dotyczący pochodzenia danych lotniczych.

W praktycznej implementacji proponowanej metody, wartości szerokości pola tolerancji $-T$ i wartości nominalnej $-N$, będą przyjmowane zgodnie z wymaganiami prawnymi [9] i specyfikacjami [15], a wartości odchylenia standardowego $-\sigma$ i wartości średniej $-\mu$ będą obliczane na bieżąco, i razem będa determinowały wartości wskaźnika $-C_{P N}$, a tym samym określały konieczne do podjęcia działania.

W praktycznym zastosowaniu proponowanej metody statystycznego zapewnienia jakości danych lotniczych istotnym zagadnieniem będzie ustanowienie szczegółowych algorytmów i procedur stosowania metody Six-Sigma, łącznie z przypisaniem poszczególnym jednostkom i podmiotom zakresów zadań, uprawnień i odpowiedzialności. 
The concept of a method ensuring aeronautical data quality

Koncepcja metody zapewnienia jakości danych lotniczych

Przyjmując do praktycznego stosowania normę ISO $13053[3,4]$ (w tym zasadę DMAIC) zostaną jednoznacznie zdefiniowane wymagania, miary, kryteria i algorytmy analizy zgodności jakościowej danych lotniczych, procedury działań doskonalących (zapobiegawczych, korygujących) oraz struktury i zasady monitorowania zgodności, w całym łańcuchu (rozpatrywanym jako proces) gromadzenia i przetwarzania danych lotniczych, w sposób obejmujący wszystkich uczestników (podmioty i służby żeglugi powietrznej) tego procesu i z uwzględnieniem prawnie określonych zakresów ich kompetencji.

Zagadnienia te będą przedmiotem dalszej pracy autorów.

\section{Wnioski}

Procesy legislacyjne UE w zakresie dotyczącym lotnictwa cywilnego wprowadzają nowe wymagania, których nadrzędnym celem jest zapewnienie bezpieczeństwa ruchu i transportu lotniczego. W pakietach przepisów SES I i II oraz Rozporządzenia (UE) nr 73/2010 i innych dokumentach związanych zostały określone wymagania i specyfikacje dotyczące jakości danych lotniczych, które odwołują się w określonych zakresach do wybranych norm ISO. Wymagania te znacząco wykraczają poza normy ICAO, zarówno w odniesieniu do poziomu wymagań, jak i metod postępowania oraz zakresów odpowiedzialności podmiotów uczestniczących $\mathrm{w}$ procesie gromadzenia i przetwarzania danych lotniczych. Trudności występujące $\mathrm{w}$ praktycznym spełnieniu tych wymagań, co może mieć również wpływ na obniżenie poziomu bezpieczeństwa ruchu lotniczego, wynikają z faktu pewnych braków wprowadzonych regulacji. Wprowadzone regulacje prawne dotyczą tylko jednostkowych kontroli zgodności danych lotniczych. Powoduje to konieczność opracowania metody bieżącej oceny i ciągłego zapewnienia jakości danych i informacji lotniczych, zgodnie z wprowadzonymi wymaganiami prawnymi. Rozpatrując zagadnienie gromadzenia i przetwarzania danych lotniczych jako proces oraz uwzględniając, że z mocy analizowanych przepisów prawnych wprowadzone są wymagania stosowania określonych norm ISO, zaproponowano zastosowanie metody statystycznego zarządzania jakością procesu, zgodnie z normą ISO 13053 [3,4], uwzględniając fakt, że aktualne wydania poszczególnych norm ISO tworzą zbiór norm zharmonizowanych, wzajemnie komplementarnych w celu i przedmiocie stosowania.

\section{Literatura}

[1] Dudek E., Kozłowski M.: Zagadnienie bezpieczeństwa zintegrowanych informacji operacyjnych w porcie lotniczym, Logistyka 4/2015, str. 183-192.

[2] Hamrol A., Mantura W.: Zarządzanie jakością - teoria i praktyka. PWN, Warszawa - Poznań 1998. 
[3] ISO 13053-1:2011, Quantitative methods in process improvement - Six Sigma - Part 1: DMAIC methodology.

[4] ISO 13053-2:2011, Quantitative methods in process improvement - Six Sigma - Part 2: Tools and techniques.

[5] Kozłowski M., Stelmach A.: Implementacja narzędzi zarządzania jakością w systemie zarządzania bezpieczeństwem na lotnisku, Instytut Badań Systemowych Polska Akademia Nauk, Seria Badania Systemowe, Tom 63, Warszawa 2008, str. 257-266.

[6] PN-EN ISO 9000:2015-10, Systemy zarządzania jakością - Podstawy i terminologia.

[7] PN-EN ISO 19157:2014:04, Informacja Geograficzna - Jakość danych (wersja angielska), 2014.

[8] PN-ISO/IEC 27001:2007, Technika informatyczna - Techniki bezpieczeństwa - Systemy zarządzania bezpieczeństwem informacji, Polski Komitet Normalizacyjny, 2007, Warszawa.

[9] Rozporządzenie Komisji (UE) nr 73/2010 z dnia 26 stycznia 2010r. ustanawiające wymagania dotyczące jakości danych i informacji lotniczych dla jednolitej europejskiej przestrzeni powietrznej.

[10] Rozporządzenie Parlamentu Europejskiego i Rady (WE) nr 216/2008 z dnia 20 lutego 2008 r. w sprawie wspólnych zasad w zakresie lotnictwa cywilnego i utworzenia Europejskiej Agencji Bezpieczeństwa Lotniczego oraz uchylające dyrektywę Rady 91/670/EWG, rozporządzenie (WE) nr 1592/2002 i dyrektywę 2004/36/WE.

[11] Rozporządzenie Parlamentu Europejskiego i Rady (WE) nr 1070/2009 z dnia 21 października 2009 r. zmieniające rozporządzenia (WE) nr 549/2004, (WE) nr 550/2004, (WE) nr 551/2004, (WE) nr 552/2004 w celu poprawienia skuteczności działania i zrównoważonego rozwoju europejskiego systemu lotnictwa.

[12] Rozporządzenie (WE) nr 549/2004 Parlamentu Europejskiego i Rady z dnia 10 marca 2004r. ustanawiające ramy tworzenia Jednolitej Europejskiej Przestrzeni Powietrznej.

[13] Rozporządzenie (WE) nr 550/2004 Parlamentu Europejskiego i Rady Unii Europejskiej z dnia 10 marca w sprawie zapewniania służb nawigacji lotniczej w Jednolitej Europejskiej Przestrzeni Powietrznej.

[14] Rozporządzenie (WE) nr 552/2004 Parlamentu Europejskiego i Rady z dnia 10 marca 2004r. w sprawie interoperacyjności Europejskiej Sieci Zarządzania Ruchem Lotniczym (Rozporządzenie w sprawie interoperacyjności).

[15] Specyfikacja EUROCONTROL - Wymagania jakości danych lotniczych, nr referencyjny dokumentu: EUROCONTROL-SPEC-152.

[16] Wodecka - Hyjek A.: Zastosowanie metody Six Sigma do doskonalenia wybranego procesu produkcyjnego w przedsiębiorstwie, Zeszyty Naukowe Akademii Ekonomicznej w Krakowie, Nr 736/2007, str. 61-73. 
The concept of a method ensuring aeronautical data quality Koncepcja metody zapewnienia jakości danych lotniczych

[17] Załącznik 11 do Konwencji o międzynarodowym lotnictwie cywilnym, Służby Ruchu Lotniczego, Organizacja Międzynarodowego Lotnictwa Cywilnego, lipiec 2001.

[18] Załącznik 14 do Konwencji o międzynarodowym lotnictwie cywilnym, Lotniska, Organizacja Międzynarodowego Lotnictwa Cywilnego, lipiec 2009.

[19] Załącznik 15 do Konwencji o międzynarodowym lotnictwie cywilnym, Służby Informacji Lotniczej, Organizacja Międzynarodowego Lotnictwa Cywilnego, lipiec 2013.

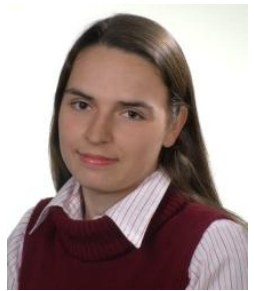

mgr inz. Ewa Dudek pracuje na stanowisku asystenta w Zaktadzie Telekomunikacji w Transporcie na Wydziale Transportu Politechniki Warszawskiej. Zainteresowania naukowe obejmuja telematyke transportu, integracje systemów, zagadnienia, zwiazane $z$ ruchem lotniczym oraz automatyke procesów ciagłych. (Udziat: 50\%).

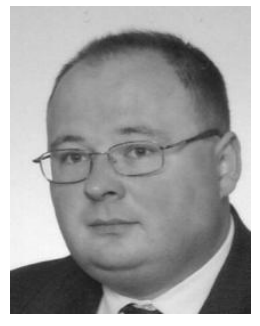

Michat Kozlowski - Adiunkt w Zakładzie Inżynierii Transportu Lotniczego Wydziatu Transportu Politechniki Warszawskiej.

Bogate doświadczenie $w$ zakresie zarzadzania portem lotniczym, wyniesione $z$ ponad dwudziestoletniej pracy zawodowej $w$ obszarze operacyjnym Lotniska Chopina $w$ Warszawie. Autor licznych badań, publikacji i wdrożeń, m.in. z zakresu systemów zarzadzania, $w$ tym bezpieczeństwem $i$ przepustowościa. (Udziat: 50\%). 